\title{
Is There Enough Evidence to Avoid Remdesivir Use in Patients with Severe Renal Impairment? A Review of the Pharmacological and Clinical Literature
}

\author{
Şiddetli Böbrek Yetmezliği Olan Hastalarda Remdesivir Kullanımından Kaçınmak için Yeterli \\ Kanıt Var mı? Farmakolojik ve Klinik Literatürün Gözden Geçirilmesi
}

\author{
(1) Suresh J. ANTONY ${ }^{1}$, (1) Emily L. HEYDEMANN², (1) Katrina M. BROWN ${ }^{3}$ \\ ${ }^{1}$ Texas Tech University Health Sciences, Section of Infectious Diseases, Department of Medicine, Texas, United States \\ 2 University of Texas Health Science Center at San Antonio Long School of Medicine, Texas, United States \\ ${ }^{3}$ Burrell College of Osteopathic Medicine, New Mexico, United States
}

\section{Abstract}

Although patients with severe renal impairment (SRI) typically experience more critical symptoms once infected with novel coronavirus, Severe Acute Respiratory Syndrome Coronavirus-2, this population has often been excluded from randomized controlled trials (RCT) for Coronavirus disease-2019 (COVID-19) treatment strategies. Of particular note, all RCTs for remdesivir (Veklury ${ }^{\circledR}$ ), the only antiviral treatment approved by the Food and Drug Administration for COVID-19 intervention, excluded patients with an estimated glomerular filtration rate less than $30 \mathrm{ml} / \mathrm{min}$. Regardless, some physicians have ventured to utilize this drug on patients with SRI, positing that the benefits might outweigh the risks of its use. The intent of this literature review was to examine the pharmacology of remdesivir and evaluate the published clinical literature on the topic to determine more definitively whether it might be safe to use in this population. A total of 59 articles were evaluated, seven of which contained descriptions of SRI patients treated with remdesivir for COVID-19, for a total of 176 patients. Interestingly, none of the patients experienced severe adverse reactions attributable to the use of remdesivir, and none of the investigators recommended against its use. While there is not yet clear evidence to suggest improvement in mortality, decreased morbidity and duration of illness are likely to lower mortality rates among these patients. Therefore, these findings suggest that, for patients with SRI diagnosed with COVID-19, the benefits of using remdesivir likely outweigh the risks. RCTs are urgently needed to further elucidate outcomes among this population.

Keywords: Remdesivir, COVID-19, severe renal impairment, end stage renal disease, therapeutics

Şiddetli böbrek yetmezliği (SRI) olan hastalar, yeni koronavirüs Ağır Akut Solunum Sendromu Koronavirüs-2 ile enfekte olduktan sonra tipik olarak daha kritik semptomlar göstermelerine rağmen, bu popülasyon Koronavirüs hastalığı-2019 (COVID-19) tedavi stratejileri için genellikle randomize kontrollü çalışmaların (RCT) dışında bırakılmıştır. Özellikle belirtmek gerekir ki, COVID-19 için Gıda ve İlaç Dairesi tarafından onaylanan tek antiviral tedavi olan remdesivirin (Veklury ${ }^{\circledR}$ ) bütün RCT'leri, tahmini glomerüler filtrasyon hızı $30 \mathrm{ml} /$ dakikadan az olan hastaları kapsam dışı bırakmıştır. Her şeye rağmen, bazı hekimler bu ilacı SRI'li hastalarda kullanma girişiminde bulunarak, yararlarının kullanımının risklerinden daha ağır basabileceğini öne sürdüler. Bu literatür taramasının amacı, remdesivir farmakolojisini incelemek ve bu popülasyonda kullanımının güvenli olup olmadığını daha kesin olarak belirlemek için konuyla ilgili yayınlanmış klinik literatürü değerlendirmekti. Yedi tanesi COVID-19 için remdesivir ile tedavi edilen SRI'li hastaların tanımlarını içeren toplam 59 makale ve 176 hasta değerlendirildi. İlginç bir şekilde, hastaların hiçbiri remdesivir kullanımına atfedilebilecek ciddi advers reaksiyonlar yaşamadı ve hiçbir araştırmacı remdesivir kullanımına karşı öneride bulunmadı. Mortaliteyi azalttığına dair henüz net kanıt olmamakla birlikte, azalmış morbidite ve kısalmış hastalık süresi, bu hastalarda ölüm oranlarını muhtemelen düşürmektedir. Bu nedenle, bu bulgular, COVID-19 teşhisi konan SRI'li hastalarda remdesivir kullanmanın yararlarının muhtemelen risklerinden daha ağır bastığını göstermektedir. Bu popülasyonda remdesivir kullanımının sonuçlarını daha fazla aydınlatmak için RCT'lere acilen ihtiyaç vardır.

Anahtar Kelimeler: Remdesivir, COVID-19, şiddetli böbrek yetmezliği, son dönem böbrek hastalığı, terapötikler

Cite this article as: Antony SJ, Heydemann EL, Brown KM. Is There Enough Evidence to Avoid Remdesivir Use in Patients with Severe Renal Impairment? A Review of the Pharmacological and Clinical Literature. Mediterr J Infect Microb Antimicrob. 2021;10:14. 


\section{Introduction}

Severe renal impairment (SRI), defined in the literature as estimated glomerular filtration rate (eGFR) $<30 \mathrm{ml} / \mathrm{min}$ [chronic kidney disease (CKD) stages 4 or 5], end stage renal disease (ESRD), and/or reliance on renal replacement therapy (RRT) ${ }^{[1]}$, has been observed to be associated with worse outcomes following Coronavirus disease-2019 (COVID-19) infection ${ }^{[2-4]}$. Patients with SRI are more likely to require intensive care treatment, undergo mechanical ventilation ${ }^{[5]}$, and generally experience longer hospitalizations ${ }^{[6]}$. They more frequently succumb to critical COVID-19-related symptoms, including a heightened inflammatory response, venous thrombosis, and multi-system organ failure ${ }^{[3]}$.

Along with increased morbidities, mortality rates from COVID-19 are also higher among patients with SRI. Within the CKD population, the mortality rate may be greater than $30 \%$, which is considerable when compared to the 2-3\% mortality observed in the general population ${ }^{[7,8]}$. High mortality rates are, in part, due to CKD-associated demographic factors and comorbidities, including older age, hypertension, cardiovascular disease, and diabetes; however, SRI-related serum markers alone, including elevated baseline creatinine, blood urea nitrogen (BUN), proteinuria, and hematuria, all correlate to increased risk for in-hospital death, even when the abovementioned factors are controlled ${ }^{[3,9]}$. Mortality rates are even more pronounced in patients on RRT, ranging up to $42 \%$ in hospitalized patients ${ }^{[10]}$. Once SRI patients are admitted to the ICU, these rates can increase to almost 55\% among patients with ESRD ${ }^{[11]}$.

While it is clear that there is an exigent need for interventions in this population, few RCTs on COVID-19 therapies have included patients with SRI. For example, in their review of 193 phase-3 randomized-controlled trials on possible COVID-19 therapies, Chewcharat et al. ${ }^{[12]}$ found that 83 (43.0\%) excluded patients with a medical history significant for pre-existing kidney disease. All clinical trials for remdesivir (brand name Veklury ${ }^{\circ}$ ), the only Food and Drug Administration (FDA) approved COVID-19 treatment thus far, have excluded patients with clinical indicators for kidney disease ${ }^{[12-16]}$. As such, this drug has not been recommended in patients with $\mathrm{SRI}^{[13,17]}$. Nonetheless, physicians have ventured to utilize remdesivir in the SRI population out of a desperate need to intervene in this at-risk and highly prevalent group, considering the benefits to outweigh the risks.

The purpose of this review is to investigate the pharmacology of the drug remdesivir and identify the reasons why it was contraindicated in patients with SRI. We will also examine research that has been conducted on remdesivir use in patients with SRI. Finally, we will evaluate the data to determine whether, despite the claims, remdesivir may be safe when used in this population.

An online search of the international literature was conducted using PubMed, Medline, and Google Scholar databases. We searched for articles published since December 2019 using the following criteria: "Remdesivir" AND "end-stage renal disease" OR "ESRD" OR "chronic kidney disease" OR "CKD" OR "GS441524 OR "SBECD" OR "renal" OR "kidney." We considered all articles available in full-text format, written in English, that discussed the use of remdesivir in patients with SRI, whether those patients had severe CKD, ESRD, renal transplant, or were on RRTs. We excluded papers that did not describe clinical outcomes, described patients with eGFR $>30 \mathrm{ml} / \mathrm{min}$, described remdesivir treatment for viruses other than COVID-19, described the use of remdesivir in healthy populations, or described patients with SRI who were not treated with remdesivir, except for use in our general analysis.

We investigated 59 journal articles, seven of which met the abovementioned criteria. These studies were based in India ${ }^{[7,18]}$, $\mathrm{USA}^{[1,19-21]}$, and France ${ }^{[22]}$, and contained a total of 176 patients with clinical indicators for SRI. The salient findings of these studies are summarized in Table 1 . They will be described following a brief introduction to the pharmacology of remdesivir and related concerns regarding its use in renallyimpaired patients.

\section{Remdesivir}

1. Background: Remdesivir (brand name Veklury ${ }^{\circledR}$ ), produced by Gilead Sciences, Inc., was originally developed during the 2014-2016 Ebola outbreak in West Africa ${ }^{[23]}$. On October 22, 2020, it became the first medication approved by the FDA specifically for use in the treatment of adult and pediatric patients 12 years or older, weighing at least $55 \mathrm{~kg}$ with Severe Acute Respiratory Syndrome Coronavirus-2 (SARS-CoV-2) (COVID-19) requiring hospitalization ${ }^{[24]}$. This approval came five months after remdesivir received an Emergency Use Authorization (EUA) in May 2020 as a result of its demonstrated efficacy in the three randomized placebo-controlled trials: The first, conducted by the National Institute of Allergy and Infectious Disease, showed a reduction in median recovery time by an average of 10 days compared to 15 days in the placebo group $(p<0.001)^{[14]}$. A decrease in overall mortality was also seen, but not statistically significant, and there was no significant difference in adverse events between the groups. The greatest observed clinical benefit was seen in patients on supplemental oxygen compared to those requiring mechanical ventilation ${ }^{[14]}$. The second $\mathrm{RCT}$ showed a statistically significant improvement in symptoms with a fiveday course of treatment compared to both a 10-day course of treatment and standard of care treatment ${ }^{[15]}$, whereas the 
Table 1. Studies evaluating the use of remdesivir in patients with severe renal impairment

\begin{tabular}{|c|c|c|c|c|c|c|c|}
\hline Reference & $\begin{array}{l}\text { No. of } \\
\text { patients } \\
\text { treated } \\
\text { with RDV }\end{array}$ & Location & Study design & $\begin{array}{l}\text { Date } \\
\text { of RDV } \\
\text { initiation }\end{array}$ & $\begin{array}{l}\text { Reported } \\
\text { adverse events } \\
\text { following RDV } \\
\text { administration }\end{array}$ & Outcomes & Conclusions \\
\hline $\begin{array}{l}\text { Thakare } \\
\text { et al. }{ }^{[18]}\end{array}$ & 46 & India & $\begin{array}{l}\text { Single-center } \\
\text { observational } \\
\text { study of } 157 \\
\text { patients with } \\
\text { ESRD or AKI } \\
\text { admitted to the } \\
\text { ICU, } 46 \text { of whom } \\
\text { were treated with } \\
\text { RDV }\end{array}$ & $\begin{array}{l}\text { Median: HD } \\
5 \text { (Range: } \\
\text { HD 1-26) }\end{array}$ & $\begin{array}{l}\text { Infusion reaction } \\
\text { (1 patient) } \\
\text { Gout (1 patient) } \\
\text { Transient } \\
\text { behavioral } \\
\text { changes ( } 5 \\
\text { patients) } \\
\text { Grade } 1 \text { AST/ } \\
\text { ALT elevations ( } 3 \\
\text { patients) }\end{array}$ & $\begin{array}{l}\text { Mortality } \\
\text { rate }=30.4 \% \\
\text { Discharge } \\
\text { rate }=52.2 \% \\
\text { Outcome pending } \\
\text { at date of } \\
\text { publication }=17.3 \%\end{array}$ & $\begin{array}{l}\text { RDV was well-tolerated } \\
\text { among patients with ESRD } \\
\text { and AKI. Controlled studies } \\
\text { are needed to evaluate } \\
\text { safety and efficacy. }\end{array}$ \\
\hline $\begin{array}{l}\text { Pettit } \\
\text { et al. }{ }^{[1]}\end{array}$ & 20 & USA & $\begin{array}{l}\text { Non-randomized } \\
\text { control study } \\
\text { of } 20 \text { patients } \\
\text { with SRI and } \\
115 \text { without SRI } \\
\text { treated with RDV }\end{array}$ & NR & $\begin{array}{l}\text { AST/ALT elevations } \\
\text { ( } 2 \text { patients) } \\
\text { SCr elevations to } \\
\text { 1.5x baseline ( } 4 \\
\text { patients) }\end{array}$ & $\begin{array}{l}\text { Mortality } \\
\text { rate }=25 \%\end{array}$ & $\begin{array}{l}\text { No significant difference in } \\
\text { frequency of adverse events } \\
\text { between SRI and non-SRI } \\
\text { group, and there were no } \\
\text { unexpected SBECD toxicities. } \\
\text { Recommend weighing the } \\
\text { benefits versus risks of using } \\
\text { RDV in this population } \\
\text { until further studies are } \\
\text { conducted evaluating its } \\
\text { safety. }\end{array}$ \\
\hline $\begin{array}{l}\text { Estiverne } \\
\text { et al. }{ }^{[21]}\end{array}$ & 18 & USA & $\begin{array}{l}\text { Multi-center, } \\
\text { observational, } \\
\text { retrospective } \\
\text { case-series of } \\
18 \text { patients with } \\
\text { eGFR }<30 \mathrm{ml} / \mathrm{min} \\
\text { treated with RDV } \\
\text { for COVID-19 }\end{array}$ & $\begin{array}{l}\text { Median: SD } \\
7 \text { (Range: } \\
\text { SD 3-10.5) }\end{array}$ & $\begin{array}{l}\text { AST/ALT elevations } \\
\text { (5 patients) } \\
\text { Increased SCr (4 } \\
\text { patients) } \\
\text { Hyperglycemia ( } 2 \\
\text { patients) } \\
\text { Anemia (1 patient) } \\
\text { Burning at } \\
\text { infusion site (1 } \\
\text { patient) }\end{array}$ & $\begin{array}{l}\text { Mortality } \\
\text { rate }=44 \% \\
\text { Discontinuation } \\
\text { rate }=28 \% \\
\text { Discharge } \\
\text { rate }=28 \%\end{array}$ & $\begin{array}{l}\text { Only one patient } \\
\text { experienced worsening } \\
\text { kidney function attributed to } \\
\text { the administration of RDV, } \\
\text { and the mortality rate was } \\
\text { similar to that expected in } \\
\text { this population. The greatest } \\
\text { benefit for RDV is in patients } \\
\text { requiring supplemental } \\
\text { oxygen versus mechanical } \\
\text { ventilation. Recommended } \\
\text { urgent further studies in } \\
\text { patients with SRI }\end{array}$ \\
\hline $\begin{array}{l}\text { Ackley } \\
\text { et al. }{ }^{[19]}\end{array}$ & 40 & USA & $\begin{array}{l}\text { Multi-center } \\
\text { matched cohort } \\
\text { of } 347 \text { patients } \\
\text { treated with RDV, } \\
40 \text { with } \mathrm{eCrCl} \\
<30 \mathrm{ml} / \mathrm{min}\end{array}$ & NR & $\begin{array}{l}\text { AKI ( } 2 \text { patients- } \\
\text { not attributed to } \\
\text { RDV) }\end{array}$ & $\begin{array}{l}\text { Mortality } \\
\text { rate }=55.9 \%\end{array}$ & $\begin{array}{l}\text { RDV did not result in } \\
\text { increased incidence of } \\
\text { EOT } \mathrm{AKI} \text { among patients } \\
\text { with } \mathrm{eCrCl}<30 \mathrm{ml} / \mathrm{min} \\
\mathrm{compared} \text { to those with } \\
\mathrm{eCrCl}>30 \mathrm{ml} / \mathrm{min} \text {. RDV could } \\
\text { be considered for severe } \\
\text { COVID-19 infections in this } \\
\text { population. Further study is } \\
\text { needed. }\end{array}$ \\
\hline $\begin{array}{l}\text { Aiswarya } \\
\text { et al. } .^{[7]}\end{array}$ & 48 & India & $\begin{array}{l}\text { Observational, } \\
\text { prospective } \\
\text { study of } 48 \\
\text { hemodialysis- } \\
\text { dependent } \\
\text { patients treated } \\
\text { with RDV }\end{array}$ & \begin{tabular}{|l} 
HD 2 \\
(Range HD \\
$1-3$ )
\end{tabular} & $\begin{array}{l}\text { ACS (1 patient) } \\
\text { Worsening } \\
\text { behavioral } \\
\text { disorder ( } 1 \\
\text { patient) }\end{array}$ & $\begin{array}{l}\text { Mortality } \\
\text { rate }=20.8 \%\end{array}$ & $\begin{array}{l}\text { Use of RDV in ESRD patients } \\
\text { was not associated with } \\
\text { serious adverse events and } \\
\text { was safe. It had more benefit } \\
\text { in reducing duration of } \\
\text { illness among patients who } \\
\text { received it within } 48 \text { hours } \\
\text { of admission. }\end{array}$ \\
\hline
\end{tabular}


Table 1. Continued

\begin{tabular}{|c|c|c|c|c|c|c|c|}
\hline Reference & $\begin{array}{l}\text { No. of } \\
\text { patients } \\
\text { treated } \\
\text { with RDV }\end{array}$ & Location & Study design & $\begin{array}{l}\text { Date } \\
\text { of RDV } \\
\text { initiation }\end{array}$ & $\begin{array}{l}\text { Reported } \\
\text { adverse events } \\
\text { following RDV } \\
\text { administration }\end{array}$ & Outcomes & Conclusions \\
\hline $\begin{array}{l}\text { Lê } \\
\text { et al. }{ }^{[22]}\end{array}$ & 1 & France & $\begin{array}{l}\text { Case study of } \\
\text { a patient with } \\
\text { bilateral lung } \\
\text { transplant one } \\
\text { year prior to } \\
\text { diagnosis with } \\
\text { COVID-19 treated } \\
\text { with RDV }\end{array}$ & HD 21 & Persistent AKI & $\begin{array}{l}\text { Death due to } \\
\text { VAP-associated } \\
\text { vasoplegic shock } \\
\text { and sepsis }\end{array}$ & $\begin{array}{l}\text { For patients in ICU } \\
\text { settings, particularly those } \\
\text { experiencing multiple organ } \\
\text { failure, hemodialysis may } \\
\text { provide an effective means } \\
\text { of maintaining a patient's } \\
\text { tolerance to RDV, as it } \\
\text { removes both GS-441524 } \\
\text { and SBECD. Further studies } \\
\text { are needed to determine } \\
\text { whether RDV is safe at } \\
\text { standard dosing. }\end{array}$ \\
\hline $\begin{array}{l}\text { Davis } \\
\text { et al. }{ }^{[20]}\end{array}$ & 3 & USA & $\begin{array}{l}\text { Case study } \\
\text { describing } \\
\text { three patients } \\
\text { with ESRD on } \\
\text { hemodialysis } \\
\text { following } \\
\text { treatment with } \\
\text { RDV }\end{array}$ & $\begin{array}{l}\text { P1: HD2 } \\
\text { P2: HD3 } \\
\text { P3: HD2 }\end{array}$ & $\begin{array}{l}\text { P1: Mild } \\
\text { transaminitis } \\
\text { peaking on HD } 7 \\
\text { (AST } 71 \mathrm{U} / \mathrm{L} ; \mathrm{ALT} \\
89 \mathrm{U} / \mathrm{L}) \\
\text { P2: None } \\
\text { P3: None }\end{array}$ & $\begin{array}{l}\text { P1: D/C HD } 13 \\
\text { P2: D/C HD } 13 \\
\text { P3: D/C HD } 7\end{array}$ & $\begin{array}{l}\text { Although accumulation of } \\
\text { GS- } 441524 \text { was observed } \\
\text { in all three patients, it was } \\
\text { removed by hemodialysis, } \\
\text { and RDV was well tolerated } \\
\text { overall. Further studies are } \\
\text { needed to determine dosing } \\
\text { strategies for renally- } \\
\text { impaired patients. }\end{array}$ \\
\hline
\end{tabular}

RDV: Remdesivir, ESRD: End stage renal disease, AKI: Acute kidney injury, HD: Hospital day, AST: Aspartate aminotransferase, ALT: Alanine aminotransferase, SRI: Severe renal

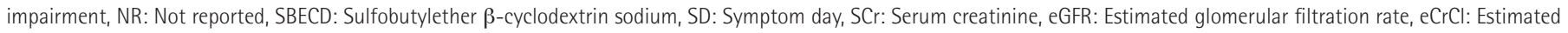
creatinine clearance, EOT: End of treatment, ACS: Acute coronary syndrome, VAP: Ventilator-associated pneumonia, ICU: Intensive care unit, COVID-19: Coronavirus disease-2019

third trial showed no significant difference in efficacy or safety between five and 10-day courses of treatment ${ }^{[16]}$. Three other randomized clinical trials of remdesivir are currently active or recruiting ${ }^{[23,25]}$.

2. Pharmacology: Remdesivir is a nucleoside analogue prodrug that is converted intracellularly to an active nucleoside triphosphate, GS-443902. This active metabolite inhibits viral replication through the RNA-dependent RNA polymerase, which is required for early replication during the infectious cycle ${ }^{[23,25]}$. It acts on coronavirus by competing with endogenous nucleotides for incorporation into the virus's replicating RNA, ultimately resulting in termination of the growing RNA chain ${ }^{[4,13,23]}$. In vitro studies determined that remdesivir is effective against a SARS-CoV-2 isolate in human airway epithelial cells at a $50 \%$ effective concentration (EC50) of $9.9 \mathrm{nM}$ following 48 hours of treatment ${ }^{[13]}$. Remdesivir has also been shown to have broad-spectrum activity against other coronaviruses [SARSCoV, Middle East Respiratory Syndrome (MERS)-CoV], some filoviruses (Ebola virus, Marburg virus), and paramyxoviruses (respiratory syncytial virus, Nipah virus, and Hendra virus) ${ }^{[17]}$.

Standard dosing begins with a $200 \mathrm{mg}$ loading dose, followed by $100 \mathrm{mg}$ per day for at least five and no more than 10 days ${ }^{[13]}$. Due to limited oral bioavailability, a result of extensive firstpass metabolism, it is administered intravenously (IV), either in solution or lyophilized powder formulation ${ }^{[13,17,23]}$. Remdesivir quickly reaches peak plasma concentration by the end of infusion, regardless of dosage, followed by rapid decline, with a half-life of approximately one hour ${ }^{[13]}$. The plasma protein binding rate of remdesivir is $88 \%$ and $2 \%$ for its predominant circulating metabolite, GS-441524, and it has wide tissue distribution ${ }^{[13,26,27]}$. Following administration, remdesivir is almost immediately converted to GS-704277, an intermediate alanine derivative, and then to GS-441524, the nucleoside monophosphate analogue that is the primary circulating metabolite ${ }^{[13,23,26]}$. This intermediate, GS-441524, has a halflife of 24.5 hours, while the active metabolite, GS-443902, has a more prolonged half-life of 40 hours in peripheral blood mononuclear cells ${ }^{[23]}$.

The pharmacokinetic (PK) profile of both remdesivir and GS-441524 is linear between doses of 3 and $225 \mathrm{mg}$, with remdesivir having no accumulation and GS-441524 reaching steady state at day four, with accumulation of about 2-fold with standard dosing ${ }^{[17,23,27]}$. The day five $A U C_{\text {tau }}$ was $1.56 \mathrm{~h}^{*} \mu \mathrm{g} /$ $\mathrm{ml}$ for remdesivir and $2.23 \mathrm{~h}^{*} \mu \mathrm{g} / \mathrm{ml}$ for GS-441524, and day five peak plasma concentrations $\left(\mathrm{C}_{\max }\right)$ were $2.61 \mu \mathrm{g} / \mathrm{ml}$ and 0.142 $\mu \mathrm{g} / \mathrm{ml}$, respectively (see Table 2$)^{[17,23]}$.

Approximately $74 \%$ of the drug is renally-excreted, with the majority concentration being GS-441524 (49\%), followed by remdesivir (10\%) and other metabolites ${ }^{[13]}$. This finding has led researchers to theorize that plasma exposure to GS-441524 
Table 2. Comparison of pharmacokinetic parameters between healthya and severe renal impairment (SRI) patients (healthy/SRI)

\begin{tabular}{l|l|l|l|l}
\hline & Half-life (hours) & AUC-day $5(\mathbf{h} \times \boldsymbol{\mu g} / \mathbf{m l})$ & $\mathrm{C}_{\max }(\boldsymbol{\mu g} / \mathbf{m l})$ & Dialysance $(\%)$ \\
\hline Remdesivir & $\sim 1,2^{20}$ & $(1.56, \mathrm{NR})$ & $2.61, \mathrm{NR}$ & $\mathrm{N} / \mathrm{A}, \mathrm{NR}$ \\
\hline GS-441524 & $25.3^{23}, \mathrm{NR}$ & $(2.23, \mathrm{NR})$ & $0.142,1.47^{20}$ & $\mathrm{~N} / \mathrm{A}_{1} 45-49^{20,22}$ \\
\hline SBECDb & $2.0^{30}, 79.1^{30}$ & $(\mathrm{NR}, \mathrm{NR})$ & $\mathrm{NR}, \mathrm{NR}$ & $\mathrm{N} / \mathrm{A}_{1}, 46^{30}$ \\
\hline
\end{tabular}

AUC: Area under the curve; $C_{\text {max }}$ : Peak plasma concentration; NR: Not rated; N/A: Not applicable

aAll data on healthy patients based on standard dosing ${ }^{17}$

bSBECD data based on voriconazole administration ${ }^{30}$

SBECD: Sulfobutylether $\beta$-cyclodextrin sodium

may be elevated in individuals with decreased renal clearance capacity $^{[13,23,26]}$.

Additionally, the limited water solubility of remdesivir necessitates incorporation of a carrier molecule, which, in this case, is a large, cyclic oligosaccharide, sulfobutylether $\beta$-cyclodextrin sodium (SBECD $)^{[4,28,29]}$. This excipient is also utilized in other water-insoluble drugs, namely the IV infusion of antifungal voriconazole, and its PKs had mainly been evaluated through the study of that drug ${ }^{[28-30]}$, until the advent of its use in remdesivir ${ }^{[4,6]}$. Sulfobutylether $\beta$-cyclodextrin sodium is removed from the body primarily via renal excretion, with a half-life of approximately two hours for patients with normal renal function (see Table 2$)^{[4,28,29]}$. The lyophilized powder form of remdesivir contains three grams of SBECD per $100 \mathrm{mg}$ dose, whereas the liquid solution contains six grams per $100 \mathrm{mg}$ dose $\mathrm{e}^{[6]}$. Similarly to GS-441524, SBECD is removed from the body primarily through renal excretion, which has also led to concern that SBECD may accumulate in the plasma of individuals who suffer from insufficient renal function ${ }^{[13,17]}$.

The most common side effects reported during clinical evaluation included transaminase elevation, headache, nausea, and rash. Less commonly reported adverse effects involved the incidence of hypersensitivity and infusion-related reactions ${ }^{[13]}$.

\section{Concerns About Remdesivir Use in Patients with SRI}

1. Clinical trials: As stated previously, all three clinical trials for remdesivir excluded patients with eGFR $<30 \mathrm{ml} / \mathrm{min}$, with two of those trials excluding patients with eGFR $<50 \mathrm{ml} /$ $\min ^{[4,12,14-16]}$. While under EUA, remdesivir use for treatment of patients with an eGFR below the $30 \mathrm{ml} / \mathrm{min}$ threshold was not recommended, "unless the potential benefit outweigh[ed] the potential risk ${ }^{[4] "}$. However, following FDA approval, this clause was removed, and now states that remdesivir must be discontinued if eGFR falls below $30 \mathrm{ml} / \mathrm{min}^{[13]}$. This limitation may be attributed to several factors, including findings of severe renal toxicity in animal studies ${ }^{[4]}$, the incidence of acute kidney injury (AKI) in patients with COVID-19 contributing to increased mortality risk ${ }^{[4,5,9]}$, and, finally, concern regarding potentially toxic accumulation of the carrier SBECD and metabolite GS-441524 in patients with renal impairment ${ }^{[13,17]}$. Each of these factors will now be evaluated based on current available research.

2. Renal injury in animal studies: During preclinical studies of remdesivir it was discovered that, when administering a slow bolus IV of the drug to rhesus monkeys and rats, both animal models experienced severe renal toxicity ${ }^{[13,17]}$. These injuries were seen in doses as low as $5 \mathrm{mg} / \mathrm{kg} /$ day for seven days in male rhesus monkeys, and the observed abnormal findings included increased BUN, serum creatinine, renal tubular atrophy, basophilia and urinary casts. They resulted even when systemic exposures of the predominant metabolite, GS-441524, were at levels as low as 0.1 times the recommended human dose exposure ${ }^{[13,17]}$. However, it should be noted that rodent models, in particular, are not effective for evaluating the effects of remdesivir in humans, as they have limitations including rapid enzymatic degradation of the pro-drug, lower half-life of the active metabolite, GS-443902, and resistance to MERS-CoV ${ }^{[23]}$. Also, these renal injury findings were not seen in clinical trial participants ${ }^{[13]}$.

3. The incidence of AKI in patients with COVID-19: Just prior to FDA authorization in the United States, and while still under conditional marketing authorization by the European Medicines Agency (EMA), the EMA announced that their Pharmacovigilance Risk Assessment Committee were reviewing a potential safety signal following reports of AKI in patients treated with remdesivir ${ }^{[31]}$. The EMA acknowledged that the signal did not necessarily represent a causal relationship, and that COVID-19 infection in and of itself was a known cause of AKI, but reported plans to continue to monitor this potential risk $^{[31]}$.

Related to this concern, a study of international pharmacovigilance reporting of the combination of terms "acute renal failure" and "remdesivir" from February to August 2020, identified a statistically significant disproportionality signal, with 138 observed cases located compared to the nine expected $(p<0.0001)^{[32]}$. However, the investigators identified that multiple confounding variables might play a role in their 
findings, including virally-mediated renal injury, co-prescription of nephrotoxic drugs, and international variations in reporting ${ }^{[32]}$.

As described in the EMA announcement, several studies have noted a high incidence of AKI among patients hospitalized with COVID-19, regardless of treatment intervention. In their study of 3,993 hospitalized patients, Chan et al. ${ }^{[33]}$ reported that AKI occurred in $46 \%$. Ng et al. ${ }^{[34]}$ found that of 5,449 patients admitted with COVID-19, 36.6\% developed AKI. Differentiating whether AKI is a virally-mediated complication or remdesivirrelated toxicity presents a difficult challenge, particularly in patients with SRI, as they are already at heightened risk for developing $A K{ }^{[5,9]}$.

Two studies have sought to counter the concern that remdesivirrelated toxicity may be associated with $\mathrm{AKI}$ : In an observational study of 224 patients, 99 of whom were treated with remdesivir and 125 receiving supportive care, the investigators found that remdesivir use was not associated with significantly increased risk for $\mathrm{AKI}^{[35]}$. Also, in their (pre-print) meta-analysis of 18 crosssectional studies, including 15,135 hospitalized patients, Xu et al. ${ }^{[36]}$ found no statistically significant association between the use of remdesivir and increased risk for AKI. However, neither of these studies looked specifically at patients with SRI.

\section{Literature Review and Discussion Regarding Published Data}

The risks of remdesivir use in patients with SRI remained purely theoretical until several studies were published evaluating its effects in this population. A total of seven studies were identified through a literature review, including five focused on general use of remdesivir in SRI patients, and two which more specifically discussed the active circulating metabolite of concern, GS-441524. The findings from these studies will now be described (see Table 1).

1. Clinical findings: In the first study, 46 patients with ESRD and CKD were admitted to the ICU for COVID-19, and were treated with a standard course of remdesivir ${ }^{[18]}$. The investigators found that remdesivir was well-tolerated overall, with no reactions severe enough to result in treatment discontinuation, and no renal function abnormalities attributable to the drug itself. Side effects included one case of gout, one infusion reaction, five cases of transient behavioral changes, and three cases of liver enzyme elevations. The mortality rate among their study group was $30.4 \%$, which is comparable to that of the general population of patients with $\mathrm{CKD}^{[7,8]}$, but lower than that seen in other studies of CKD patients admitted to the ICU ${ }^{[11]}$.

The second was a retrospective chart review of 135 patients following treatment with remdesivir, 20 of whom had been diagnosed with $\mathrm{SRI}^{[1]}$. The investigators found that, compared to the patients without SRI, the overall rate of adverse events secondary to remdesivir was not significantly different (30\% vs. $11 \%, p=0.26)$, despite seeing increased rates of serum creatinine elevation and alanine aminotransferase/aspartate aminotransferase (ALT/AST) elevations in the SRI group. However, they did observe a significantly higher mortality rate in the SRI group (25\%) compared to non-SRI patients (3.5\%, $p=0.004)^{[1]}$. This increased mortality rate was attributed to pre-existing disorders, as well as their associated morbidities, rather than the drug remdesivir in and of itself ${ }^{[1]}$. It was also lower than that generally seen in the published literature ${ }^{[7-9,11,37]}$. The investigators concluded with the recommendation that remdesivir be used in patients with SRI to reduce the time to recovery, reflecting that its benefits outweighed the risk of its use $^{[1]}$.

In a multi-center, observational, retrospective case series of adults treated with remdesivir for COVID-19, a total of 18 patients with eGFR $<30 \mathrm{ml} / \mathrm{min}$ were included ${ }^{[21]}$. The investigators found that, over the course of treatment, two patients developed ALT elevations greater than five times the upper limit of normal; however, these elevations were not attributed to remdesivir. They also observed three cases of ALT abnormalities attributed to remdesivir, but none with elevations high enough to result in discontinuation. A majority of the patients with eGFR $<30$ $\mathrm{ml} / \mathrm{min}$ not on RRT at the start of treatment experienced improved creatinine levels, but the condition of four patients worsened to a state which required RRT, with one of those cases being attributed to remdesivir. Other observed adverse events attributed to remdesivir included two cases of hyperglycemia, one case of anemia, and one case of burning sensation at the infusion site. Despite these events, researchers concluded that treatment was generally well-tolerated, although no impact on mortality was seen, and the overall 28-day mortality rate was $44 \%$ (8/18 patients) ${ }^{[21]}$. All of the patients who died were under intensive care at the time of remdesivir initiation, which is consistent with indications that intervention with remdesivir is most effective in patients solely in need of supplemental oxygen ${ }^{[13]}$, as well as the higher rate of mortality among patients with a concurrent renal insufficiency disorder ${ }^{[7-9,11,37]}$. In general, remdesivir was found to be safe in these patients, and particularly beneficial among those not requiring mechanical ventilation $^{[35]}$.

A second multi-center, retrospective chart review, compared outcomes between 40 patients with an estimated creatinine clearance $(\mathrm{eCrCl})<30 \mathrm{ml} / \mathrm{min}$ and 307 patients with $\mathrm{eCrCl}>30$ $\mathrm{ml} / \mathrm{min}$ who received the lyophilized powder preparation of remdesivir ${ }^{[19]}$. The investigators found no significant difference in the frequency of AKI 48 hours post-completion of treatment between patients with $\mathrm{eCrCl}<30$ and $\mathrm{eCrCl}>30 \mathrm{ml} / \mathrm{min}(5 \%$ vs. $2.3 \%, p=0.283$ ), nor did they find a significant difference in early discontinuation due to AST/ALT elevations (0\% vs. 3.9\%, $\mathrm{p}=0.374$ ). Similar to the studies mentioned previously, the 
30-day mortality rate was higher among patients with $\mathrm{eCrCl}$ $<30 \mathrm{ml} / \mathrm{min}$ ( $50 \%$ vs. $16.2 \%, \mathrm{p}<0.001)$. This difference was accounted for by underlying variables such as the increased age of these patients, increased number and range of comorbidities, medications, and greater likelihood of mechanical ventilation requirement ${ }^{[19]}$. The investigators concluded that remdesivir may serve as a viable option for patients with SRI who are experiencing severe COVID-19 infections ${ }^{[33]}$.

One observational, prospective study looked specifically at outcomes in 48 patients on hemodialysis following treatment with remdesivir for COVID-19 ${ }^{[7]}$. The results indicated that remdesivir was well tolerated, no significant elevations in AST/ ALT were observed, and a significant decline in serum C-reactive protein was seen among all participants $(p<0.001)$, along with an improvement in oxygen requirement among 68.5\% of the patients on low-flow oxygen support at admission. The investigators also found that, when administered within 48 hours of hospitalization, remdesivir shortened hospitalization by an average of 5.5 days $(p=0.001)$. Despite this benefit, mortality rates were not improved among those who started remdesivir early (within 48 hours) compared to those whose treatment was initiated later (after 48 hours of admission) $(p=0.34)^{[7]}$. However, while the overall mortality of $20.8 \%$ was comparable to other ESRD patients with COVID-19 infection being treated within the same facility (17.9\%), it was lower than that seen in other studies of patients with $\operatorname{ESRD}^{[2,8,38]}$. It was concluded that that remdesivir use in ESRD patients was safe, and especially beneficial if used soon after hospital admission ${ }^{[7]}$.

Overall, these five studies indicate that remdesivir is likely safe for use in patients with SRI, particularly if started early in the course of treatment. However, due to the lack of randomized controlled trials, and the paucity of studies conducted so far, further research is needed to fully elucidate its role in the care of these patients.

2. The question of metabolite and excipient accumulation in patients with SRI: The final point of concern related to the use of remdesivir in SRI patients is the potentially pathogenic roles of the major circulating metabolite, GS-441524 and the excipient SBECD. Two papers thus far have examined GS441524 in this population (see Table 1): First, in a case report of a double-lung transplant patient who had received remdesivir late in his clinical course ${ }^{[22]}$, the accumulation of GS-441524 was observed to a trough concentration $\left(\mathrm{C}_{\text {trough }}\right)$ of $0.563 \mu \mathrm{g} /$ $\mathrm{ml}$, more than four times the peak plasma concentration $\left(\mathrm{C}_{\max }\right)$

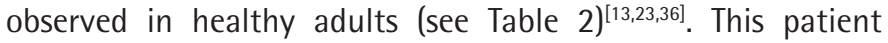
experienced renal failure 3-days post initiation of remdesivir, and was placed on hemodialysis, wherein 59\% of GS-441524 was removed ${ }^{[22]}$. Whether accumulation of this metabolite contributed to the patient's renal injury is not definitive, as it likely resulted from multiple factors, including coinfections, the use of immunosuppressants and multiple antibiotics, and prolonged hospitalization. However the investigators concluded that, should accumulation of GS-441524 be suspected as the cause of kidney injury, it can be effectively removed by hemodialysis ${ }^{[22]}$.

In the second, the investigators monitored levels of GS-441524 in three patients with ESRD requiring hemodialysis following a five-day course of remdesivir treatment ${ }^{[20]}$. They noted that the half-life of remdesivir was approximately twice as long in patients with ESRD compared to healthy adults $(\sim 2 \mathrm{~h}$ versus $\sim 1 \mathrm{~h}$ ), and that $\mathrm{C}_{\max }$ for GS-441524 reached a level 10 times higher than the $\mathrm{C}_{\max }$ at day five among healthy adults $(1.47 \mu \mathrm{g} / \mathrm{ml} \text { vs. } 0.142 \mu \mathrm{g} / \mathrm{ml})^{[20,23]}$, however this level declined quite dramatically following administration of hemodialysis, with resultant concentrations 45-49\% lower than pre-dialysis levels (see Table 2). Despite accumulation of the GS-441524 metabolite, the drug itself was well tolerated by all of the observed patients, and all patients were discharged following treatment ${ }^{[20]}$.

Related to the metabolite GS-441524 is the transient appearance of GS-704277, which has been associated with the incidence of renal toxicity in rat models through activity against organic anion transporters (OATs) ${ }^{[39]}$. However, this can likely be excluded as GS-704277 is not a human OAT substrate ${ }^{[17]}$. As such it is not likely to impact the renal system in the same manner as it does in the rat model ${ }^{[17,22]}$. Of note, a recent pharmacologic evaluation concluded that GS-441524 should be investigated as a possible safe and efficacious alternative to remdesivir, lending credence to it being an unlikely point of concern in for toxicity in the SRI population ${ }^{[39]}$.

An area of more focused attention has been the role of the excipient, SBECD, in patients with renal impairment. Similar to GS-441524, the concern in these patients lies in the fact that it, too, is renally-cleared ${ }^{[13]}$. Although animal studies have shown that accumulated plasma levels of SBECD contributes to subsequent development of liver necrosis and renal tubular obstruction, the doses utilized in these studies were 50- to 100-times higher than expected in the longest recommended course of remdesivir treatment, 10 days ${ }^{[1,4]}$.

The greatest dosage of SBECD that would be found in the remdesivir solution contains $6 \mathrm{~g}$ per $100 \mathrm{mg}^{[13]}$. This is well below the safety threshold dose of $250 \mathrm{mg} / \mathrm{kg} /$ day as recommended by the $\mathrm{EMA}^{[1,4,17]}$. It is also similar to the dose found in voriconazole, which contains 6.4 grams of SBECD, a dose which has not been associated with renal adverse events ${ }^{[1,4]}$. However, SBECD can accumulate significantly in patients with ESRD: In their study of 13 patients treated with five days of IV voriconazole, Luke et al. ${ }^{[30]}$ found that the mean $\mathrm{T} 1 / 2$ of SBECD was 2.1 hours in normal subjects and 79.1 hours 
among those receiving dialysis; however dialysis successfully removed $46 \%$ of the SBECD and shortened the half-life to 5.0 hours (see Table 2). Despite the significant half-life prolongation, investigators concluded that clinical doses of SBECD are unlikely to result in adverse events, even in patients with renal insufficiency ${ }^{[30]}$. Although no specific studies have been conducted elucidating the role of SBECD in remdesivir in the SRI population, neither studies of voriconazole nor remdesivir have shown evidence of nephrotoxicity, even in patients with underlying renal disease ${ }^{[1,4,19]}$. This has resulted in the recommended use of remdesivir despite concerns related to SBECD accumulation ${ }^{[40]}$.

\section{Conclusion}

Due to the lack of RCTs on remdesivir in patients with SRI, and as a result of the fact that it remains one of the only approved medications for the treatment of COVID-19 infection, its use thus far has been a matter of weighing benefits against potential consequences. We have evaluated the primary areas of concern regarding the drug, such as toxicities in animal studies, the association with AKI, and the question of metabolite and excipient accumulation, and, based on current evidence, determined them to be more theoretically than clinically relevant. While some concerns remain, including the EMA announcement regarding a potential safety signal related to remdesivir use and AKI, and the findings of GS-441524 and SBECD accumulation in patients with SRI not on RRT, the results are clear: Among the studies published, there were no serious adverse side effects or worsening of the clinical syndrome related to the administration of remdesivir. More importantly, of the investigators who evaluated remdesivir use in the clinical population, none oppose its use in patients with $\mathrm{SRI}^{[1,7,18-22]}$. Until evidence becomes available that this medication results in worse outcomes than the virus itself, its use should be considered in this population.

What is clear is that, as the COVID-19 pandemic rages on, patients with SRI are dying at startling rates: In a case report of 94 patients on hemodialysis, 42\% of patients expired after being hospitalized for COVID-19 ${ }^{[38]}$. Individuals who have received kidney transplants are also at increased risk of mortality from COVID-19, with rates nearing $30 \% \%^{[5]}$. The highest mortality rates can be seen among SRI patients admitted to the ICU: According to their multicenter cohort study of 65 ICUs in the United States, Gupta et al. ${ }^{[11]}$ found that the 28-day mortality was $47.1 \%$ for patients with CKD and $54.7 \%$ for patients with ESRD.

Therefore, it is suggested by the authors that remdesivir is likely safe to use in patients with renal insufficiency, provided they are apprised of the lack of RCT safety data in patients with eGFR $<30 \mathrm{ml} / \mathrm{min}$ and closely monitored. By limiting viral replication, and thus reducing viral load in these patients, clinical symptoms will be mitigated. This will allow patients to be discharged from the hospital sooner, likely reducing high morbidity and mortality rates ${ }^{[1,7,18,19]}$. In conclusion, prudent use of the antiviral medication remdesivir will allow clinicians to fill a critical gap in the management of patients with SRI who are diagnosed with COVID-19.

Peer-review: Externally and internally peer-reviewed.

\section{Authorship Contributions}

Surgical and Medical Practices: S.J.A., Concept: S.J.A., E.L.H., Design: S.J.A., E.L.H., K.M.B., Data Collection or Processing: S.J.A., E.L.H., K.M.B., Analysis or Interpretation: S.J.A., E.L.H., K.M.B., Literature Search: S.J.A., E.L.H., K.M.B., Writing: S.J.A., E.L.H., K.M.B.

Conflict of Interest: No conflict of interest was declared by the authors.

Financial Disclosure: The authors declared that this study received no financial support.

\section{References}

1. Pettit NN, Pisano J, Nguyen CT, Lew AK, Hazra A, Sherer R, Mullane K. Remdesivir Use in the Setting of Severe Renal Impairment: A Theoretical Concern or Real Risk? Clin Infect Dis. 2020;14:1851.

2. Corbett RW, Blakey S, Nitsch D, Loucaidou M, McLean A, Duncan N, Ashby DR; West London Renal and Transplant Centre. Epidemiology of COVID-19 in an Urban Dialysis Center. J Am Soc Nephrol. 2020;31:1815-23.

3. Flythe JE, Assimon MM, Tugman MJ, Chang EH, Gupta S, Shah J, Sosa MA, Renaghan AD, Melamed ML, Wilson FP, Neyra JA, Rashidi A, Boyle SM, Anand S, Christov M, Thomas LF, Edmonston D, Leaf DE; STOP-COVID Investigators. Characteristics and Outcomes of Individuals With Preexisting Kidney Disease and COVID-19 Admitted to Intensive Care Units in the United States. Am J Kidney Dis. 2021;77:190-203.

4. Adamsick ML, Gandhi RG, Bidell MR, Elshaboury RH, Bhattacharyya RP, Kim AY, Nigwekar S, Rhee EP, Sise ME. Remdesivir in Patients with Acute or Chronic Kidney Disease and COVID-19. J Am Soc Nephrol. 2020;31:1384-6.

5. Gagliardi I, Patella G, Michael A, Serra R, Provenzano M, Andreucci M. COVID-19 and the Kidney: From Epidemiology to Clinical Practice. J Clin Med. 2020;9:2506.

6. Ng JH, Hirsch JS, Wanchoo R, Sachdeva M, Sakhiya V, Hong S, Jhaveri KD, Fishbane S; Northwell COVID-19 Research Consortium and the Northwell Nephrology COVID-19 Research Consortium. Outcomes of patients with end-stage kidney disease hospitalized with COVID-19. Kidney Int. 2020;98:1530-9.

7. Aiswarya $D$, Arumugam $V$, Dineshkumar $T$, Gopalakrishnan $N$, Lamech $T M$ Nithya G, Sastry BVRH, Vathsalyan P, Dhanapriya J, Sakthirajan R. Use of Remdesivir in Patients With COVID-19 on Hemodialysis: A Study of Safety and Tolerance. Kidney Int Rep. 2021;6:586-93.

8. Goicoechea M, Sánchez Cámara LA, Macias N, Muñoz de Morales A, Rojas ÁG, Bascuñana A, Arroyo D, Vega A, Abad S, Verde E, García Prieto AM, Verdalles Ú, Barbieri $D$, Delgado AF, Carbayo J, Mijaylova $A$, Acosta $A$, Melero R, Tejedor A, Benitez PR, Pérez de José A, Rodriguez Ferrero ML, Anaya $F$, Rengel M, Barraca D, Luño J, Aragoncillo I. COVID-19: clinical course and outcomes of 36 hemodialysis patients in Spain. Kidney Int. 2020;98:27-34. 
9. Cheng Y, Luo R, Wang K, Zhang M, Wang Z, Dong L, Li J, Yao Y, Ge S, Xu G. Kidney disease is associated with in-hospital death of patients with COVID-19. Kidney Int. 2020;97:829-38.

10. Alberici $F$, Delbarba E, Manenti $C$, Econimo L, Valerio F, Pola A, Maffei $C$, Possenti S, Lucca B, Cortinovis R, Terlizzi V, Zappa M, Saccà C, Pezzini E, Calcaterra E, Piarulli P, Guerini A, Boni F, Gallico A, Mucchetti A, Affatato $S$, Bove $S$, Bracchi $M$, Costantino EM, Zubani R, Camerini C, Gaggia $P$, Movilli E, Bossini N, Gaggiotti M, Scolari F. A report from the Brescia Renal COVID Task Force on the clinical characteristics and short-term outcome of hemodialysis patients with SARS-CoV-2 infection. Kidney Int. 2020;98:206.

11. Gupta S, Hayek SS, Wang W, Chan L, Mathews KS, Melamed ML, Brenner SK, Leonberg-Yoo A, Schenck EJ, Radbel J, Reiser J, Bansal A, Srivastava A, Zhou Y, Sutherland A, Green A, Shehata AM, Goyal N, Vijayan A, Velez JCQ, Shaefi S, Parikh CR, Arunthamakun J, Athavale AM, Friedman AN, Short SAP, Kibbelaar ZA, Abu Omar S, Admon AJ, Donnelly JP, Gershengorn $H B$, Hernán MA, Semler MW, Leaf DE; STOP-COVID Investigators. Factors Associated With Death in Critically III Patients With Coronavirus Disease 2019 in the US. JAMA Intern Med. 2020;180:1-12.

12. Chewcharat $A$, Chang $Y T$, Sise ME, Bhattacharyya RP, Murray MB, Nigwekar SU. Phase-3 Randomized Controlled Trials on Exclusion of Participants With Kidney Disease in COVID-19. Kidney Int Rep. 2021;6:196-9.

13. Gilead Sciences Canada, Inc. VEKLURY ${ }^{\circledR}$ (Remdesivir) powder for solution for infusion \&t solution product monograph - notice of compliance with conditions. 2020:1-30. Accessed date: December 27, 2020.

14. Beigel JH, Tomashek KM, Dodd LE, Mehta AK, Zingman BS, Kalil AC, Hohmann E, Chu HY, Luetkemeyer A, Kline S, Lopez de Castilla D, Finberg RW, Dierberg K, Tapson V, Hsieh L, Patterson TF, Paredes R, Sweeney DA, Short WR, Touloumi G, Lye DC, Ohmagari N, Oh MD, Ruiz-Palacios GM, Benfield T, Fätkenheuer G, Kortepeter MG, Atmar RL, Creech CB, Lundgren J, Babiker AG, Pett S, Neaton JD, Burgess TH, Bonnett T, Green M, Makowski M, Osinusi A, Nayak S, Lane HC; ACTT-1 Study Group Members. Remdesivir for the Treatment of Covid-19 - Final Report. N Engl J Med. 2020;383:1813-26.

15. Spinner CD, Gottlieb RL, Criner GJ, Arribas López JR, Cattelan AM, Soriano Viladomiu A, Ogbuagu O, Malhotra P, Mullane KM, Castagna A, Chai LYA, Roestenberg M, Tsang OTY, Bernasconi E, Le Turnier P, Chang SC, SenGupta D, Hyland RH, Osinusi AO, Cao H, Blair C, Wang H, Gaggar A, Brainard DM, McPhail MJ, Bhagani S, Ahn MY, Sanyal AJ, Huhn G, Marty FM; GS-US-540-5774 Investigators. Effect of Remdesivir vs Standard Care on Clinical Status at 11 Days in Patients With Moderate COVID-19: A Randomized Clinical Trial. JAMA. 2020;324:1048-57.

16. Goldman JD, Lye DCB, Hui DS, Marks KM, Bruno R, Montejano R, Spinner CD, Galli M, Ahn MY, Nahass RG, Chen YS, SenGupta D, Hyland RH, Osinusi AO, Cao H, Blair C, Wei X, Gaggar A, Brainard DM, Towner WJ, Muñoz J, Mullane KM, Marty FM, Tashima KT, Diaz G, Subramanian A; GS-US-540-5773 Investigators. Remdesivir for 5 or 10 Days in Patients with Severe Covid-19. N Engl J Med. 2020;383:1827-37.

17. European Medicines Agency. Summary on compassionate use: Remdesivir Gilead. Accessed date: 03 April 2020.

18. Thakare S, Gandhi C, Modi T, Bose S, Deb S, Saxena N, Katyal A, Patil A, Patil S, Pajai A, Bajpai D, Jamale T. Safety of remdesivir in patients with acute kidney injury or CKD. Kidney Int Rep. 2021;6:206-10.

19. Ackley TW, McManus D, Topal JE, Cicali B, Shah S. A Valid Warning or Clinical Lore: an Evaluation of Safety Outcomes of Remdesivir in Patients with Impaired Renal Function from a Multicenter Matched Cohort. Antimicrob Agents Chemother. 2021;65:e02290-20.

20. Davis MR, Pham CU, Cies JJ. Remdesivir and GS-441524 plasma concentrations in patients with end-stage renal disease on haemodialysis. J Antimicrob Chemother. 2021;76:822-5.

21. Estiverne C, Strohbehn IA, Mithani Z, Hirsch JS, Wanchoo R, Goyal PG, Lee Dryden-Peterson S, Pearson JC, Kubiak DW, Letourneau AR, Bhattacharyya $R$, Jhaveri KD, Sise ME. Remdesivir in Patients With Estimated GFR $<30$ $\mathrm{ml} / \mathrm{min}$ per $1.73 \mathrm{~m}^{2}$ or on Renal Replacement Therapy. Kidney Int Rep. 2021;6:835-8.

22. Lê MP, Le Hingrat $Q$, Jaquet P, Wicky PH, Bunel V, Massias L, Visseaux B, Messika J, Descamps D, Mal H, Timsit JF, Peytavin G. Removal of Remdesivir's Metabolite GS-441524 by Hemodialysis in a Double Lung Transplant Recipient with COVID-19. Antimicrob Agents Chemother. 2020;64:e0152120.

23. Jorgensen SCJ, Kebriaei R, Dresser LD. Remdesivir: Review of Pharmacology, Pre-clinical Data, and Emerging Clinical Experience for COVID-19. Pharmacotherapy. 2020;40:659-71.

24. U.S. Food \& Drug Administration. FDA approves first treatment for COVID-19. Published October 22, 2020. Accessed date: January 3, 2021.

25. Barlow A, Landolf KM, Barlow B, Yeung SYA, Heavner JJ, Claassen CW, Heavner MS. Review of Emerging Pharmacotherapy for the Treatment of Coronavirus Disease 2019. Pharmacotherapy. 2020;40:416-37.

26. Lamb YN. Remdesivir: First Approval. Drugs. 2020;80:1355-63.

27. Marra $F$, Smolders EJ, El-Sherif 0 , Boyle A, Davidson $K$, Sommerville AJ, Marzolini C, Siccardi M, Burger D, Gibbons S, Khoo S, Back D. Recommendations for Dosing of Repurposed COVID-19 Medications in Patients with Renal and Hepatic Impairment. Drugs R D. 2021;21:9-27.

28. Kiser $T H$, Fish $D N$, Aquilante $C L$, Rower $J E$, Wempe $M F$, MacLaren $R$, Teitelbaum I. Evaluation of sulfobutylether- $\beta$-cyclodextrin (SBECD) accumulation and voriconazole pharmacokinetics in critically ill patients undergoing continuous renal replacement therapy. Crit Care. 2015;19:32.

29. Hafner V, Czock D, Burhenne J, Riedel KD, Bommer J, Mikus G, Machleidt C, Weinreich T, Haefeli WE. Pharmacokinetics of sulfobutylether-betacyclodextrin and voriconazole in patients with end-stage renal failure during treatment with two hemodialysis systems and hemodiafiltration. Antimicrob Agents Chemother. 2010;54:2596-602.

30. Luke DR, Wood ND, Tomaszewski KE, Damle B. Pharmacokinetics of sulfobutylether- $\beta$-cyclodextrin (SBECD) in subjects on hemodialysis. Nephrol Dial Transplant. 2012;27:1207-12.

31. European Medicines Agency. Meeting highlights from the Pharmacovigilance Risk Assessment Committee (PRAC) 28 September - 1 October 2020. European Medicines Agency; 2020. Accessed date: December 27, 2020.

32. Gérard AO, Laurain A, Fresse $A$, Parassol N, Muzzone $M$, Rocher $F$, Esnault VLM, Drici MD. Remdesivir and Acute Renal Failure: A Potential Safety Signal From Disproportionality Analysis of the WHO Safety Database. Clin Pharmacol Ther. 2020 Dec 19.

33. Chan L, Chaudhary K, Saha A, Chauhan K, Vaid A, Zhao S, Paranjpe I, Somani S, Richter F, Miotto R, Lala A, Kia A, Timsina P, Li L, Freeman R, Chen R, Narula J, Just AC, Horowitz C, Fayad Z, Cordon-Cardo C, Schadt E, Levin MA, Reich DL, Fuster V, Murphy B, He JC, Charney AW, Böttinger EP, Glicksberg BS, Coca SG, Nadkarni GN; Mount Sinai COVID Informatics Center (MSCIC). AKI in Hospitalized Patients with COVID-19. J Am Soc Nephrol. 2021;32:151-60.

34. $\mathrm{Ng} J \mathrm{H}$, Hirsch JS, Hazzan A, Wanchoo R, Shah HH, Malieckal DA, Ross DW, Sharma P, Sakhiya V, Fishbane S, Jhaveri KD; Northwell Nephrology COVID-19 Research Consortium. Outcomes Among Patients Hospitalized With COVID-19 and Acute Kidney Injury. Am J Kidney Dis. 2021;77:204-15.

35. Kalligeros $M$, Tashima KT, Mylona EK, Rybak N, Flanigan TP, Farmakiotis $D$, Beckwith CG, Sanchez M, Neill M, Johnson JE, Garland JM, Aung S, Byrd KM, O'Brien T, Pandita A, Aridi J, Macias Gil R, Larkin J, Shehadeh F, Mylonakis E. Remdesivir Use Compared With Supportive Care in Hospitalized Patients With Severe COVID-19: A Single-Center Experience. Open Forum Infect Dis. 2020;7:319.

36. Xu Y, Barauskas O, Kim C, Babusis D, Murakami E, Kornyeyev D, Lee G, Stepan G, Perron M, Bannister R, Schultz BE, Sakowicz R, Porter D, Cihlar T, Feng JY. Off-Target In Vitro Profiling Demonstrates that Remdesivir Is a Highly Selective Antiviral Agent. Antimicrob Agents Chemother. 2021;65:e0223720. 
37. Williamson EJ, Walker AJ, Bhaskaran $\mathrm{K}$, Bacon $\mathrm{S}$, Bates $\mathrm{C}$, Morton $\mathrm{CE}$, Curtis HJ, Mehrkar A, Evans D, Inglesby P, Cockburn J, McDonald HI, MacKenna B, Tomlinson L, Douglas IJ, Rentsch CT, Mathur R, Wong AYS, Grieve R, Harrison D, Forbes H, Schultze A, Croker R, Parry J, Hester F, Harper S, Perera R, Evans SJW, Smeeth L, Goldacre B. Factors associated with COVID-19-related death using OpenSAFELY. Nature. 2020;584:430-6.

38. Boni $F$, Gallico $A$, Mucchetti $A$, Affatato $S$, Bove $S$, Bracchi M, Costantino EM, Zubani R, Camerini C, Gaggia P, Movilli E, Bossini N, Gaggiotti M, Scolari F. A report from the Brescia Renal COVID Task Force on the clinical characteristics and short-term outcome of hemodialysis patients with SARS-CoV-2 infection. Kidney Int. 2020;98:20-6.

39. Yan VC, Muller FL. Captisol and GS-704277, but Not GS-441524, Are Credible Mediators of Remdesivir's Nephrotoxicity. Antimicrob Agents Chemother. 2020;64:e01920-20.

40. Avdic E, Chalk BS. Remdesivir, Johns Hopkins ABX Guide; 2020. Available from: https://www.hopkinsguides.com/hopkins/view/Johns_Hopkins_ABX_ Guide/540753/all/Remdesivir 